\title{
Metode Seleksi Fitur Untuk Klasifikasi Sentimen Menggunakan Algoritma Naive Bayes: Sebuah Literature Review
}

\author{
Fitria Septianingrum*, Agung Susilo Yuda Irawan
}

\author{
Fakultas Ilmu Komputer, Teknik Informatika, Universitas Singaperbangsa Karawang, Karawang, Indonesia \\ Email: 1," fitria.septia17101@ @ student.unsika.ac.id, ${ }^{2}$ agung@unsika.ac.id \\ Email Penulis Korespondensi: fitria.septia17101@ student.unsika.ac.id
}

\begin{abstract}
Abstrak-Pada zaman revolusi industri 4.0 seperti saat ini, di mana internet merupakan suatu kebutuhan bagi masyarakat dalam menjalani kehidupan sehari-hari. Intensitas dari penggunaan internet yang tinggi di lingkungan masyarakat, maka menyebabkan persebaran suatu informasi didalamnya pun dapat tersebar secara luas dan cepat. Adanya persebaran informasi yang cepat di internet maka sejalan pula dengan pertumbuhan data digital yang semakin besar, sehingga opini-opini publik yang terdapat didalamnya menjadi hal yang penting. Karena, dari data digital tersebut dapat diolah dengan analisis sentimen guna memperoleh suatu informasi yang bermanfaat mengenai isu yang sedang berkembang di lingkungan masyarakat ataupun untuk mengetahui opini publik terhadap suatu produk perusahaan. Banyaknya penelitian terkait analisis sentimen yang menerapkan algoritma Naive Bayes guna menyelesaikan masalahnya, maka peneliti tertarik untuk melakukan penelitian mengenai penggunaan seleksi fitur terhadap algoritma tersebut. Maka dari itu, dilakukannya penelitian ini guna mengetahui seleksi fitur apa yang paling optimal ketika di kombinasikan dengan algoritma Naive Bayes dengan menggunakan metode penelitian Systematic Literature Review (SLR). Hasil penelitian ini disimpulkan bahwa metode seleksi fitur yang paling optimal ketika dikombinasikan dengan algoritma Naive Bayes adalah metode Particle Swarm Optimization (PSO) dengan nilai rata-rata akurasi $89.08 \%$.
\end{abstract}

Kata Kunci: Analisis Sentimen; Media Sosial; Metode Seleksi Fitur; Algoritma Naive Bayes; Systematic Literature Review

Abstract-In the era of the industrial revolution 4.0 as it is today, where the internet is a necessity for people to live their daily lives. The high intensity of internet use in the community, it causes the distribution of information in it to spread widely and quickly. The rapid distribution of information on the internet is also in line with the growing growth of digital data, so that the public opinions contained therein become important things. Because, from this digital data, it can be processed with sentiment analysis in order to obtain useful information about issues that are developing in the community or to find out public opinion on a company's product. The number of studies related to sentiment analysis that applies the Naive Bayes algorithm to solve the problem, so researchers are interested in conducting research on the use of feature selection for the algorithm. Therefore, this research was conducted to determine what feature selection is the most optimal when combined with the Naive Bayes algorithm using the Systematic Literature Review (SLR) research method. The results of this study concluded that the most optimal feature selection method when combined with the Naive Bayes algorithm is the Particle Swarm Optimization (PSO) method with an average accuracy value of $89.08 \%$.

Keywords: Sentiment Analysis; Social Media; Feature Selection Method; Naive Bayes Algorithm; Systematic Literature Review

\section{PENDAHULUAN}

Pada zaman serba internet seperti saat ini, di mana perkembangan teknologi berkembang semakin pesat dan cepat ke arah yang serba digital [1], penggunaan internet khususnya sosial media tentunya tidak lagi menjadi hal yang awam bagi masyarakat Indonesia. Hal ini dapat dibuktikan dengan hasil survei yang dilaksanakan oleh Hootsuite di tahun 2021 yang menunjukkan bahwa pengguna aktif platform media sosial di Indonesia saat ini mencapai angka 170 juta pengguna. Berbagai macam aktivitas yang dilakukan masyarakat di sosial media, tentu dapat menghasilkan sebuah data digital setiap harinya yang berasal dari interaksi sosial yang dibangun melalui media sosial itu sendiri. Opini merupakan pendapat pribadi dari seseorang mengenai suatu topik atau hal yang ada [2] dan opini publik saat ini menjadi suatu hal yang penting bagi perkembangan suatu perusahaan ataupun bagi kebijakan-kebijakan yang akan diambil oleh suatu pemerintahan. Data-data digital tersebut dapat berupa sebuah opini publik mengenai suatu isu yang sedang trending di kalangan masyarakat, ataupun penilaian, komentar, dan opini seorang konsumen terhadap suatu produk atau jasa yang mereka gunakan dari sebuah perusahaan produk dan jasa tersebut. Salah satu platform penghasil data digital terbanyak yaitu Media Sosial [3]. Maka dari itu, opini publik saat ini merupakan hal yang penting karena dapat mempengaruhi proses branding dari suatu perusahaan ataupun penilaian dari masyarakat terhadap kebijakan pemerintahan dan tokoh publik di Indonesia.

Setelah mengetahui pentingnya opini publik saat ini, banyak peneliti-peneliti yang mulai melakukan penelitian di bidang text mining khususnya analisis sentimen untuk melakukan klasifikasi sentimen ke dalam kelas positif, negatif, ataupun netral. Salah satu algoritma yang dapat digunakan dalam mengklasifikasi kalimat sentimen yaitu algoritma Naive Bayes [4]. Karena algoritma ini didasarkan pada asumsi penyederhanaan bahwa nilai atribut secara kondisional saling bebas apabila diberi nilai output dan keuntungan dari penggunaan algoritma Naive Bayes yaitu metode ini hanya membutuhkan training data yang kecil dalam menentukan estimasi parameter dalam proses pengklasifikasian [5] . Sedangkan kekurangan dari algoritma Naive Bayes yaitu sangat sensitif dalam proses pemilihan fitur, sehingga untuk mengatasinya yaitu dengan cara dikombinasikan dengan metode seleksi fitur [6]. Penggunaan seleksi fitur sendiri dapat berpengaruh terhadap tingkat akurasi algoritma karena dengan adanya 
seleksi fitur, maka dapat diketahui firut-fitur apa saja yang kurang relevan dan juga dapat menseleksi fitur-fitur yang memiliki informasi penting didalamnya. Penelitian ini akan melakukan Literature Review terhadap metode seleksi fitur yang dikombinasikan dengan algoritma Naive Bayes untuk mengetahui seleksi fitur apa yang paling optimal ketika dikombinasikan dengan algoritma tersebut dalam melakukan analisis sentimen publik melalui media sosial.

Pengumpulan data dilakukan dengan cara melakukan studi literatur terhadap referensi yang dikumpulkan dan paper yang digunakan pada penelitian ini merupakan paper dengan rentang waktu tahun publikasi mulai dari tahun 2016 - 2020. Sedangkan jumlah artikel penelitian yang digunakan dijadikan perbandingan akurasi nya yaitu sebanyak 25 artikel. Adapun metode seleksi fitur yang akan dijadikan bahan perbandingan yaitu seleksi fitur Information Gain, Particle Swarm Optimization (PSO), Chi Square, dan N-Gram. Tujuan penelitian ini yaitu untuk melakukan analisis perbandingan seleksi fitur yang dikombinasikan dengan algoritma Naive Bayes untuk melakukan analisis sentimen.

\section{METODOLOGI PENELITIAN}

Penelitian ini merupakan suatu Systematic Literature Review (SLR). Sumber data yang digunakan berasal dari beberapa artikel penelitian yang telah diakses dari bulan Februari-April 2021 melalui beberapa platform seperti Google Scholar, Research Gate, IEEE Xplore, dan IOP Science berupa penelitian-penelitian sebelumnya yang telah dilakukan mengenai analisis sentimen dengan menggunakan seleksi fitur dan algoritma Naive Bayes berupa artikel ilmiah, skripsi, ataupun proceeding. Adapun alur penelitian yang digunakan pada penelitian SLR ini dapat dilihat pada Gambar 1 di bawah ini.

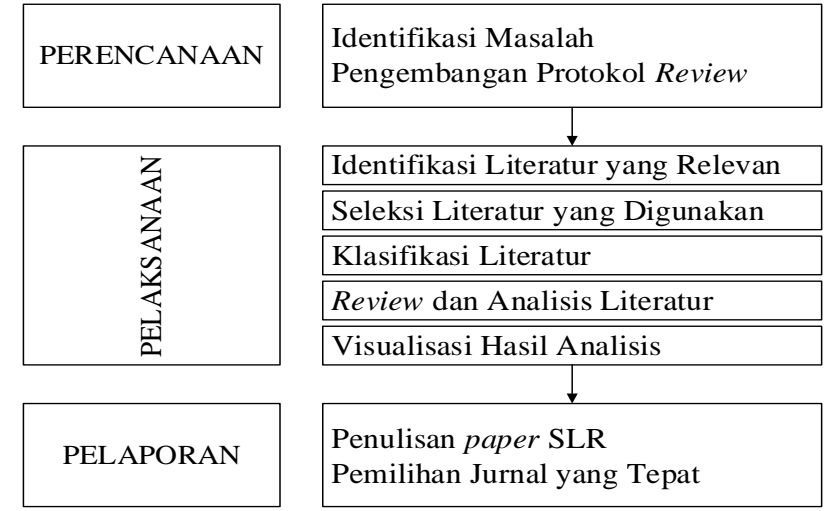

Gambar 1. Alur Penelitian

\subsection{Tahap Perencanaan}

Pada tahap pertama yaitu tahap perencanaan akan dilakukan proses identifikasi masalah mengenai penelitian dengan topik analisis sentimen menggunakan Algoritma Naive Bayes dan juga pencarian artikel terkait topik tersebut. Adapun kata kunci yang digunakan dalam melakukan pencarian artikel yaitu :
a. Analisis Sentimen dengan Algoritma Naive Bayes dan Seleksi Fitur
b. Optimalisasi Algoritma Naive Bayes dengan Penggunaan Seleksi Fitur
c. Implementasi Algoritma Naive Bayes pada Analisis Sentimen dari Media Sosial
d. Pengaruh Penggunaan Seleksi Fitur Terhadap Kinerja Algoritma Naive Bayes

\subsection{Tahap Pelaksanaan}

Selanjutnya pada tahap pelaksanaan terdiri dari 5 tahap, yaitu diantaranya :

a. Mengidentifikasi literur yang relevan dengan topik penelitian ini yaitu mengenai analisis sentimen dengan algoritma naive bayes.

b. Melakukan seleksi dari literatur-literatur yang telah didapatkan berdasarkan relevansi topik dan juga tahun publikasi paper tersebut.

c. Kemudian literatur-literatur yang telah diseleksi tersebut akan di klasifikasikan berdasarkan topik dan tahun publikasi penelitian yang telah ditentukan.

d. Melakukan proses review artikel dan juga melakukan analisis dari literatur-literatur yang ada.

e. Membuat visualisasi dari hasil analisis tersebut.

\subsection{Tahap Pelaporan}

Tahap terakhir yaitu pelaporan di mana pada tahap ini akan dilakukan penyusunan paper SLR dari proses literature review yang telah dilakukan dan juga memilih jurnal yang tepat untuk mempublikasikan paper yang telah dibuat tersebut. 
JURNAL MEDIA INFORMATIKA BUDIDARMA

Volume 5, Nomor 3, Juli 2021, Page 799-805

ISSN 2614-5278 (media cetak), ISSN 2548-8368 (media online)

Available Online at https://ejurnal.stmik-budidarma.ac.id/index.php/mib

DOI 10.30865/mib.v5i3.2983

\section{HASIL DAN PEMBAHASAN}

\subsection{Hasil Pencarian dan Klasifikasi Artikel}

Berdasarkan hasil pencarian artikel melalui platform Google Scholar sesuai dengan kata kunci yang digunakan, diperoleh data berupa artikel ilmiah, proceeding,dan skripsi dengan jumlah 25 penelitian. Artikel ilmiah tersebut dipublikasikan pada tahun 2016 sampai tahun 2020 dan memiliki topik penelitian mengenai analisis sentimen dengan menggunakan algoritma naive bayes dan seleksi fitur. Berdasarkan 25 artikel penelitian yang telah terkumpul dan diakses mulai bulan Februari hingga April tahun 2021, kemudian dilakukan proses klasifikasi berdasarkan seleksi fitur yang digunakan pada penelitian tersebut, dan juga tahun publikasi dari artikel-artikel tersebut yang dapat dilihat pada Tabel 1 dan Tabel 2 di bawah ini.

Tabel 1. Klasifikasi Artikel Berdasarkan Seleksi Fitur yang Digunakan

\begin{tabular}{ccc}
\hline No & Seleksi Fitur yang Digunakan & Jumlah \\
\hline 1 & Information Gain (IG) & 10 \\
2 & Particle Swarm Optimization (PSO) & 8 \\
3 & Chi Square & 4 \\
4 & N-Gram & 3 \\
\hline \multicolumn{2}{c}{ Tabel 2. Klasifikasi Artikel Berdasarkan Tahun Publikasi } \\
\hline No & Tahun Publikasi Penelitian & Jumlah \\
\hline 1 & 2016 & 1 \\
3 & 2017 & 4 \\
4 & 2018 & 6 \\
5 & 2019 & 8 \\
\hline
\end{tabular}

Dari hasil klasifikasi di atas, maka dapat dibuat visualisasi datanya yang tertera pada Gambar 1 dan Gambar 2 di bawah ini.

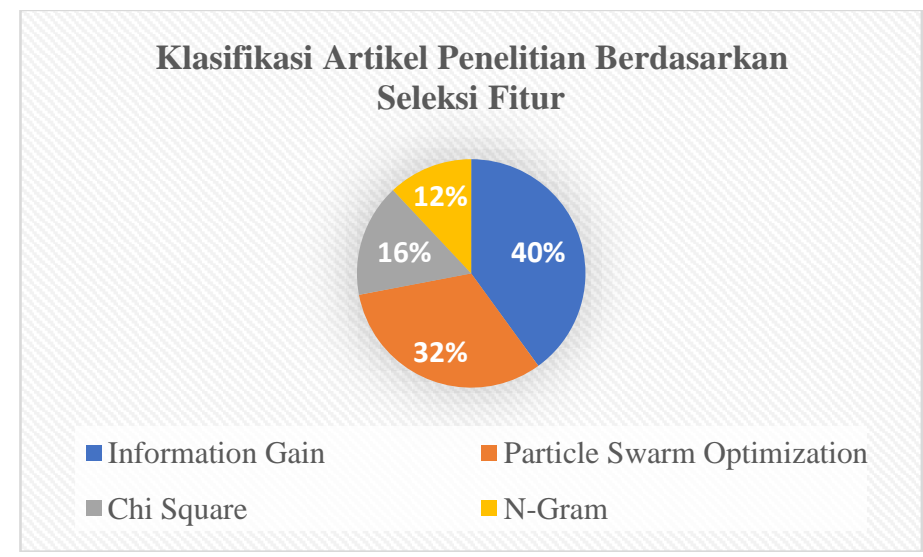

Gambar 2. Diagram Klasifikasi Artikel Penelitian Berdasarkan Seleksi Fitur

Klasifikasi Artikel Penelitian Berdasarkan Tahun Publikasi

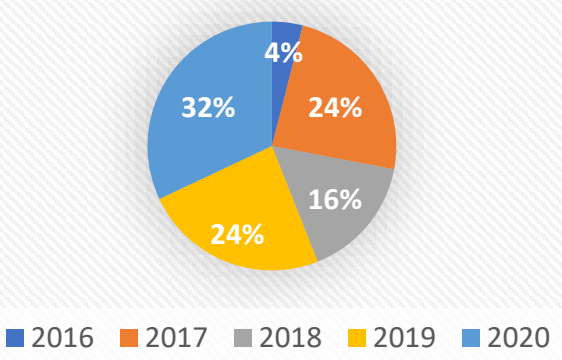

Gambar 3. Diagram Klasifikasi Artikel Penelitian Berdasarkan Tahun Publikasi 
JURNAL MEDIA INFORMATIKA BUDIDARMA

Volume 5, Nomor 3, Juli 2021, Page 799-805

ISSN 2614-5278 (media cetak), ISSN 2548-8368 (media online)

Available Online at https://ejurnal.stmik-budidarma.ac.id/index.php/mib DOI 10.30865/mib.v5i3.2983

\subsection{Review dan Analisis Literatur}

Pada tahap ini akan dilakukan review dan analisis perbandingan tingkat akurasi algoritma Naive Bayes berdasarkan seleksi fitur yang digunakan pada penelitian analisis sentimen yang dapat dilihat pada Tabel 3 berikut.

Tabel 3. Perbandingan Tingkat Akurasi Algoritma Naive Bayes Berdasarkan Metode Seleksi Fitur

\begin{tabular}{|c|c|c|c|c|c|}
\hline No & Penulis (Tahun) & Judul & $\begin{array}{c}\text { Jumlah } \\
\text { Dataset }\end{array}$ & Seleksi Fitur & $\begin{array}{l}\text { Tingkat } \\
\text { Akurasi }\end{array}$ \\
\hline 1 & $\begin{array}{l}\text { (Putri, Mubarok, } \\
\& \quad \text { Adiwijaya, } \\
2017)[7]\end{array}$ & $\begin{array}{l}\text { Klasifikasi Sentimen Ulasan Buku } \\
\text { Berbahasa Inggris Menggunakan } \\
\text { Information Gain dan Naive Bayes }\end{array}$ & 1000 & $\begin{array}{l}\text { Information } \\
\text { Gain }\end{array}$ & $88.28 \%$ \\
\hline 2 & $\begin{array}{l}\text { (Negara, } \\
\text { Muhardi, \& Putri, } \\
\text { 2020) [8] }\end{array}$ & 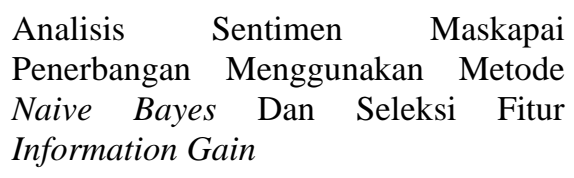 & 1000 & $\begin{array}{l}\text { Information } \\
\text { Gain }\end{array}$ & $86.5 \%$ \\
\hline 3 & $\begin{array}{l}\text { (Attabi, } \\
\text { Muflikhah, \& } \\
\text { Fauzi, 2018) [9] }\end{array}$ & $\begin{array}{l}\text { Penerapan Analisis Sentimen untuk } \\
\text { Menilai Suatu Produk pada Twitter } \\
\text { Berbahasa Indonesia dengan Metode } \\
\text { Nä̈ve Bayes Classifier dan Information } \\
\text { Gain }\end{array}$ & 200 & $\begin{array}{l}\text { Information } \\
\text { Gain }\end{array}$ & $74 \%$ \\
\hline 4 & $\begin{array}{l}\text { (Utama, Rosiyadi, } \\
\text { Aridarma, } \& \\
\text { Prakoso, 2019) } \\
{[10]}\end{array}$ & $\begin{array}{l}\text { Sentimen Analisis Kebijakan Ganjil } \\
\text { Genap Di Tol Bekasi Menggunakan } \\
\text { Algoritma Naive Bayes Dengan } \\
\text { Optimalisasi Information Gain }\end{array}$ & 440 & $\begin{array}{l}\text { Information } \\
\text { Gain }\end{array}$ & $79.55 \%$ \\
\hline 5 & $\begin{array}{l}\text { (Syakuro, 2017) } \\
{[11]}\end{array}$ & 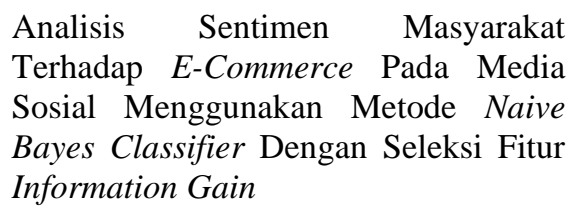 & 3000 & $\begin{array}{l}\text { Information } \\
\text { Gain }\end{array}$ & $88.8 \%$ \\
\hline 6 & $\begin{array}{l}\text { (Zaman, 2020) } \\
{[12]}\end{array}$ & $\begin{array}{l}\text { Klasifikasi Opini Terhadap Kebijakan } \\
\text { Publik Merdeka Belajar Pada Jejaring } \\
\text { Sosial Twitter Menggunakan Metode } \\
\text { Naive Bayes Dengan Seleksi Fitur } \\
\text { Information Gain }\end{array}$ & 273 & $\begin{array}{l}\text { Information } \\
\text { Gain }\end{array}$ & $81.48 \%$ \\
\hline 7 & $\begin{array}{l}\text { (Khalida \& } \\
\text { Setiawati, 2020) } \\
{[13]}\end{array}$ & $\begin{array}{l}\text { Analisis Sentimen Sistem E-Tilang } \\
\text { Menggunakan Algoritma Naive Bayes } \\
\text { Dengan Optimalisasi Information Gain }\end{array}$ & 276 & $\begin{array}{l}\text { Information } \\
\text { Gain }\end{array}$ & $41.82 \%$ \\
\hline 8 & $\begin{array}{l}\text { (Widya Sihwi, } \\
\text { Prasetya Jati, \& } \\
\text { Anggrainingsih, } \\
\text { 2018) [14] }\end{array}$ & $\begin{array}{l}\text { Twitter Sentiment Analysis of Movie } \\
\text { Reviews Using Information Gain and } \\
\text { Naive Bayes Classifier }\end{array}$ & 8231 & $\begin{array}{l}\text { Information } \\
\text { Gain }\end{array}$ & $82.19 \%$ \\
\hline 9 & $\begin{array}{l}\text { (Syahriani, Yana, } \\
\text { \& Santoso, 2020) } \\
{[15]}\end{array}$ & $\begin{array}{l}\text { Sentiment Analysis of Facebook } \\
\text { Comments on Indonesian Presidential } \\
\text { Candidates Using the Naïve Bayes } \\
\text { Method }\end{array}$ & 300 & $\begin{array}{l}\text { Information } \\
\text { Gain }\end{array}$ & $83.67 \%$ \\
\hline 10 & $\begin{array}{l}\text { (Andilala, 2016) } \\
{[16]}\end{array}$ & $\begin{array}{l}\text { Movie Review Sentimen Analisis } \\
\text { Dengan Metode Nä̈ve Bayes Base on } \\
\text { Feature Selection }\end{array}$ & 2000 & $\begin{array}{l}\text { Information } \\
\text { Gain }\end{array}$ & $95.70 \%$ \\
\hline 11 & $\begin{array}{l}\text { (Taufik, 2017) } \\
\text { [17] }\end{array}$ & $\begin{array}{l}\text { Optimasi Particle Swarm Optimization } \\
\text { Sebagai Seleksi Fitur Pada Analisis } \\
\text { Sentimen Review Hotel Berbahasa } \\
\text { Indonesia Menggunakan Algoritma } \\
\text { Nä̈ve Bayes }\end{array}$ & 200 & $\begin{array}{l}\text { Particle } \\
\text { Swarm } \\
\text { Optimization }\end{array}$ & $96.92 \%$ \\
\hline
\end{tabular}


Optimasi Naive Bayes Classifier untuk (Nugroho, Istiadi, Klasifikasi Teks pada e-government \& Marisa, 2020) Menggunakan Particle Swarm [18]

Optimization

Analisis Sentimen Opini Publik Bahasa (Hayuningtyas \& Indonesia Terhadap Wisata TMI Sari, 2019) [19] Menggunakan Naive Bayes dan PSO

Analisis Sentimen Pada Sosial Media Twitter Menggunakan Naive Bayes Classifier Dengan Feature Selection Particle Swarm Optimization Dan Term Frequency

Analisa Sentimen Dengan Algoritma 15

(Solecha, 2019) [21]

(Betesda, 2020) [22]

(Aulianita \& Rifai, 2018) [23]

(Saputra, 2019) [24] [26]

(Amrullah, Sofyan Anas, \& Hidayat, 2020) [27]

(Nisa,

22 Darwiyanto, \& Asror, 2019) [28]

(Agung Nugroho, 2018) [29]
Nä̈ve Bayes Classifier Berbasis Particle Swarm Optimization Untuk Review Restoran

Peningkatan Optimasi Sentimen Dalam Pelaksanaan Proses Pemilihan Presiden Berdasarkan Opini Publik Dengan Menggunakan Algoritma Naive Bayes dan Particle Swarm Optimization

Optimasi Particle Swarm Optimization Pada Naive Bayes Untuk Sentiment Analysis Furniture

Analisis Sentimen E-Wallet Pada Google Play Menggunakan Algoritma Naive Bayes Berbasis Particle Swarm Optimization

Kombinasi Seleksi Fitur Chi Square Dengan Algoritma Naive Bayes Untuk Analisis Sentimen Komentar Facebook

Peningkatan Performa Naive Bayes Dengan Seleksi Atribut Menggunakan Chi Square Untuk Klasifikasi Loyalitas Pelanggan GRAB

Analisis Sentimen Movie Review Menggunakan Naive Bayes Classifier Dengan Seleksi Fitur Chi Square

Analisis Sentimen Menggunakan Naive Bayes Classifier dengan Chi-Square Feature Selection Terhadap Penyedia Layanan Telekomunikasi

Analisis Sentimen Pada Media Sosial Twitter Menggunakan Naive Bayes Classifier Dengan Ekstrasi Fitur $N$ Gram

Penggunaan $\mathrm{N}$-Gram Pada Analisa Sentimen Pemilihan Kepala Daerah
Particle

$200 \quad$ Swarm

Optimization

$87.44 \%$

Particle

$100 \quad$ Swarm

$94.02 \%$

Optimization

$3300 \quad$ Particle

Swarm

$97.48 \%$

Optimization

Particle

Swarm

Optimization

$88.50 \%$

Particle

Swarm

$71.15 \%$

Optimization

Particle

$200 \quad$ Swarm

Optimization

$93.50 \%$

Particle

$300 \quad$ Swarm

Optimization

$83.60 \%$

$1000 \quad$ Chi Square $\quad 91 \%$

$331 \quad$ Chi Square $\quad 99.51 \%$

$1400 \quad$ Chi Square $\quad 64.40 \%$

$1200 \quad$ Chi Square $\quad 85.5 \%$

$300 \quad$ N-Gram $\quad 92 \%$

600

N-Gram

$82.3 \%$ 
ISSN 2614-5278 (media cetak), ISSN 2548-8368 (media online)

Available Online at https://ejurnal.stmik-budidarma.ac.id/index.php/mib DOI 10.30865/mib.v5i3.2983

Jakarta Menggunakan Algoritma Naive

Bayes

(Irvantoro, 25

Saifudin, \& Umilasari, 2019)
Feature Selection Menggunakan Chi Squared dan N-Gram Dengan Algoritma Naive Bayes Classifier Untuk Analisis Sentimen Review Produk Elektronik
600

N-Gram

$89 \%$

\subsection{Visualisasi Hasil Analisis}

Berdasarkan hasil analisis perbandingan di atas maka dapat dibuat visualisasi dari rata-rata tingkat akurasi algoritma Naive Bayes yang dikombinasikan dengan 4 jenis metode seleksi fitur guna mengetahui metode seleksi fitur terbaik apabila dikombinasikan dengan algoritma Naive Bayes. Grafik rata-rata akurasi tersebut dapat dilihat pada gambar 4 di bawah ini.

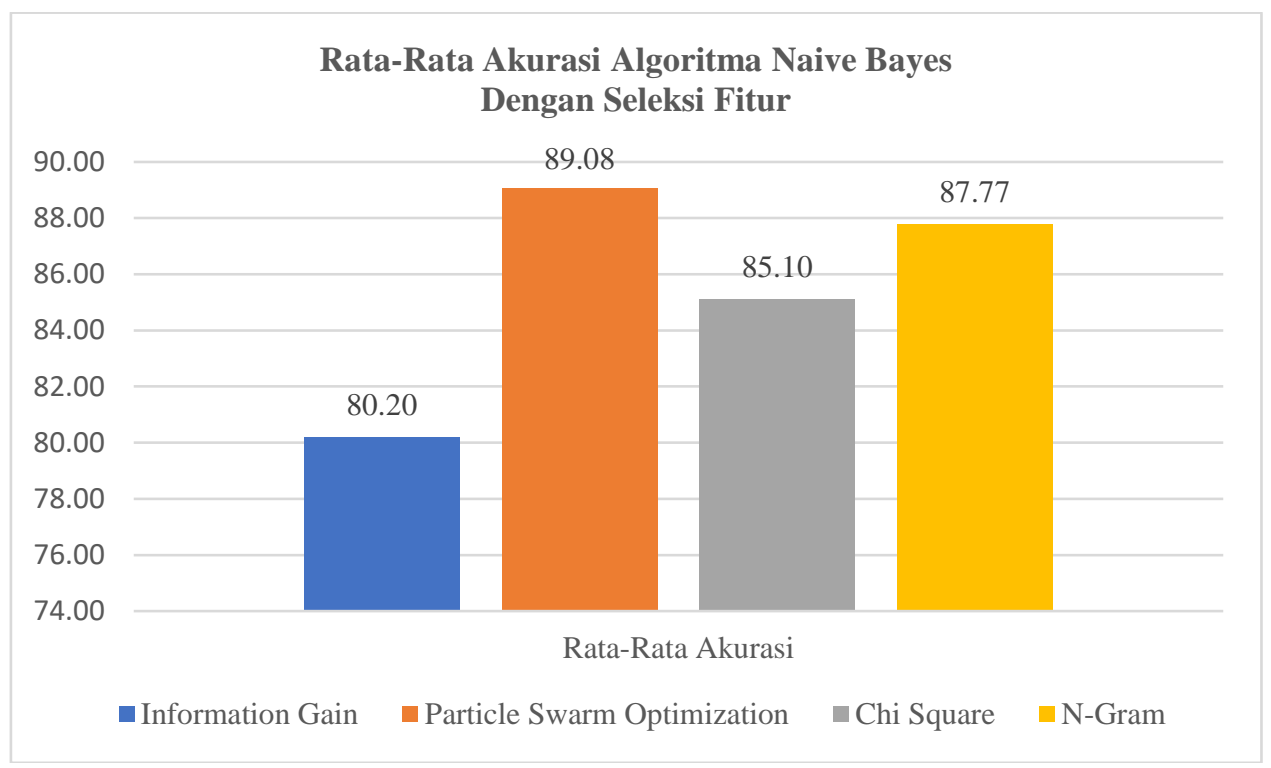

Gambar 4. Rata-Rata Akurasi dari Penggunaan Metode Seleksi Fitur Pada Algoritma Naive Bayes

\section{KESIMPULAN}

Berdasarkan literature review yang telah dilakukan dari 25 artikel ilmiah dapat diketahui bahwa seleksi fitur Particle Swarm Optimization (PSO) merupakan metode seleksi fitur yang cocok dan menghasilkan hasil terbaik apabila dikombinasikan dengan algoritma klasifikasi Naive Bayes. Tingkat akurasi dapat dipengaruhi oleh jumlah dataset yang digunakan dan juga metode seleksi fitur yang digunakan. Berdasarkan grafik perbandingan rata-rata nilai akurasi tersebut dapat diketahui bahwa kombinasi antara algoritma Naive Bayes dengan seleksi fitur Particle Swarm Optimization (PSO) memiliki nilai paling tinggi yaitu $89.08 \%$. Sedangkan rata-rata akurasi dari metode seleksi fitur $\mathrm{N}$-Gram berada dibawah PSO dengan tingkat akurasi $87.77 \%$, kemudian di bawah $\mathrm{N}$-Gram terdapat metode seleksi fitur Chi Square dengan tingkat akurasi $85.10 \%$ dan rata-rata akurasi dari seleksi fitur Information Gain yaitu $80.20 \%$.

\section{UCAPAN TERIMAKASIH}

Terima kasih disampaikan kepada Bapak Agung Susilo Yuda Irawan selaku dosen Fakultas Ilmu Komputer Universitas Singaperbangsa Karawang yang telah mendukung terlaksananya penelitian ini dan juga teman-teman yang telah memberikan saran dan masukan serta membantu penulis dalam penyusunan artikel ini.

\section{REFERENCES}

[1] R. Mahendrajaya, G. A. Buntoro, and M. B. Setyawan, "Analisis Sentimen Pengguna Gopay Menggunakan Metode Lexicon Based Dan Support Vector Machine,” Komputek, vol. 3, no. 2, p. 52, 2019, doi: 10.24269/jkt.v3i2.270.

[2] H. Himawan, W. Kaswidjanti, A. Sentimen, M. Sosial, and L. Based, "Metode Lexicon Based Dan Support Vector Machine Untuk Menganalisis Sentimen Pada Media Sosial Sebagai Rekomendasi Oleh-Oleh Favorit," vol. 2018, no. November, pp. 235-244, 2018.

[3] A. K. Fauziyyah, "Analisis Sentimen Pandemi Covid19 Pada Streaming Twitter Dengan Text Mining Python," J. Ilm. 
ISSN 2614-5278 (media cetak), ISSN 2548-8368 (media online)

Available Online at https://ejurnal.stmik-budidarma.ac.id/index.php/mib

DOI 10.30865/mib.v5i3.2983

SINUS, vol. 18 , no. 2 , p. 31, 2020, doi: 10.30646/sinus.v18i2.491.

[4] F. Ratnawati, "Implementasi Algoritma Naive Bayes Terhadap Analisis Sentimen Opini Film Pada Twitter," INOVTEK Polbeng - Seri Inform., vol. 3, no. 1, p. 50, 2018, doi: 10.35314/isi.v3i1.335.

[5] S. Rahayu, J. J. Purnama, H. M. Nawawi, and F. S. Nugraha, "Algoritma Naïve Bayes Classifier Untuk Memprediksi Gejala Autism Spectrum Disorders Pada Anak-Anak," Pros. Semin. Nas. Rekayasa dan Teknol. (TAU SNAR-TEK), vol. ISSN:, no. November, 2019.

[6] D. A. Muthia, "Sentiment Analysis on Closure of Illegal Movie Streaming Sites Using Naïve Bayes Algorithm," J. Pilar Nusa Mandiri, vol. 16, no. 1, pp. 123-128, 2020, doi: 10.33480/pilar.v16i1.1306.

[7] L. R. Putri, M. S. Mubarok, and Adiwijaya, "Klasifikasi Sentimen Ulasan Buku Berbahasa Inggris Menggunakan Information Gain Dan Naive Bayes," e-Proceeding Eng., vol. 4, 2017.

[8] A. B. P. Negara, H. Muhardi, and I. M. Putri, "Analisis Sentimen Maskapai Penerbangan Menggunakan Metode Naive Bayes dan Seleksi Fitur Information Gain," J. Teknol. Inf. dan Ilmu Komput., vol. 7, no. 3.

[9] A. W. Attabi, L. Muflikhah, and M. A. Fauzi, "Penerapan Analisis Sentimen untuk Menilai Suatu Produk pada Twitter Berbahasa Indonesia dengan Metode Naïve Bayes Classifier dan Information Gain,” J. Pengemb. Teknol. Inf. dan Ilmu Komput., vol. 2, no. 11, pp. 4548-4554, 2018.

[10] H. S. Utama, D. Rosiyadi, D. Aridarma, and B. S. Prakoso, "Sentimen Analisis Kebijakan Ganjil Genap Di Tol Bekasi Menggunakan Algoritma Naive Bayes Dengan Optimalisasi Information Gain,” J. Pilar Nusa Mandiri, vol. 15, no. 2, pp. 247-254, 2019, doi: 10.33480/pilar.v15i2.705.

[11] A. Syakuro, "Analisis Sentimen Masyarakat Terhadap E-Commerce Pada Media Sosial Menggunakan Metode Naive Bayes Classifier ( NBC ) Dengan Seleksi Fitur Information Gain ( IG ), pp. 1-89, 2017.

[12] M. R. T. Zaman, "Klasifikasi Opini Terhadap Kebijakan Publik Merdeka Belajar Pada Jejaring Sosial Twitter Menggunakan Metode Naive Bayes Dengan Seleksi Fitur Information Gain,” 2020.

[13] R. Khalida and S. Setiawati, "Analisis Sentimen Sistem E-Tilang Menggunakan Algoritma Naive Bayes Dengan Optimalisasi Information Gain,” J. Inform. Inf. Secur., vol. 1, no. 1, pp. 19-26, 2020, doi: 10.31599/jiforty.v1i1.137.

[14] S. Widya Sihwi, I. Prasetya Jati, and R. Anggrainingsih, "Twitter Sentiment Analysis of Movie Reviews Using Information Gain and Naïve Bayes Classifier," Proc. - 2018 Int. Semin. Appl. Technol. Inf. Commun. Creat. Technol. Hum. Life, iSemantic 2018, pp. 190-195, 2018.

[15] Syahriani, A. A. Yana, and T. Santoso, "Sentiment analysis of facebook comments on indonesian presidential candidates using the naïve bayes method," J. Phys. Conf. Ser., vol. 1641, no. 1, 2020, doi: 10.1088/1742-6596/1641/1/012012.

[16] A. Andilala, "Movie Review Sentimen Analisis Dengan Metode Naïve Bayes Base on Feature Selection," Pseudocode, vol. 3, no. 1, pp. 1-9, 2016, doi: 10.33369/pseudocode.3.1.1-9.

[17] A. Taufik, "Optimasi Particle Swarm Optimization Sebagai Seleksi Fitur Pada Analisis Sentimen Review Hotel Berbahasa Indonesia Menggunakan Algoritma Naïve Bayes," J. Tek. Komput. AMIK BSI, vol. III, no. 2, pp. 40-47, 2017.

[18] K. S. Nugroho, I. Istiadi, and F. Marisa, "Naive Bayes classifier optimization for text classification on e-government using particle swarm optimization," J. Teknol. dan Sist. Komput., vol. 8, no. 1, pp. 21-26, 2020, doi: 10.14710/jtsiskom.8.1.2020.21-26.

[19] R. Y. Hayuningtyas and R. Sari, "Analisis Sentimen Opini Publik Bahasa Indonesia Terhadap Wisata Tmii Menggunakan Naïve Bayes Dan Pso,” J. Techno Nusa Mandiri, vol. 16, no. 1, pp. 37-42, 2019.

[20] Y. Cahyono, "Analisis Sentiment pada Sosial Media Twitter Menggunakan Naïve Bayes Classifier dengan Feature Selection Particle Swarm Optimization dan Term Frequency,” J. Inform. Univ. Pamulang, 2017.

[21] K. Solecha, "Analisa Sentimen Dengan Algoritma Naïve Bayes Classifier Berbasis Particle Swarm Optimization Untuk Review Restoran," J. Speed - Sentra Penelit. Eng. dan Edukasi, vol. 11, no. 1.

[22] Betesda, "Peningkatan Optimasi Sentimen Dalam Pelaksanaan Proses Pemilihan Presiden Berdasarkan Opini Publik Dengan Menggunakan Algoritma Naive Bayes Dan Particle Swarm Optimization,” 2020.

[23] R. Aulianita and A. Rifai, "Optimasi Particle Swarm Optimization Pada Naive Bayes Untuk Sentiment Analysis Furniture," Inf. Manag. Educ. Prof., vol. 3, no. 1, pp. 31-40, 2018.

[24] S. A. Saputra, "Sentiment Analysis Analisis Sentimen E-Wallet Pada Google Play Menggunakan Algoritma Naive Bayes Berbasis Particle Swarm Optimization,” J. RESTI (Rekayasa Sist. dan Teknol. Informasi), vol. 3, no. 3, pp. 377-382, 2019.

[25] R. Hidayat, "Kombinasi Seleksi Fitur Chi Square Dengan Algoritma Naive Bayes Untuk Analisis Sentimen,” vol. 1, pp. 72-81, 2017.

[26] R. Y. Kisworini, "Peningkatan Performa Naive Bayes Dengan Seleksi Atribut Menggunakan Chi Square Untuk Klasifikasi Loyalitas Pelanggan GRAB,” J. Informatics, Inf. Syst. Softw. Eng. Appl., vol. 2, no. 2, pp. 69-75, 2020.

[27] A. Z. Amrullah, A. Sofyan Anas, and M. A. J. Hidayat, "Analisis Sentimen Movie Review Menggunakan Naive Bayes Classifier Dengan Seleksi Fitur Chi Square,” Jurnal, vol. 2, no. 1, pp. 40-44, 2020.

[28] A. Nisa, E. Darwiyanto, and I. Asror, "Analisis Sentimen Menggunakan Naive Bayes Classifier dengan Chi-Square Feature Selection Terhadap Penyedia Layanan Telekomunikasi," e-Proceeding Eng., vol. 6, no. 2, pp. 8650-8659, 2019.

[29] A. Nugroho, "Analisis Sentimen Pada Media Sosial Twitter Menggunakan Naive Bayes Classifier Dengan Ekstrasi Fitur N-Gram," J-SAKTI (Jurnal Sains Komput. dan Inform., vol. 2, no. 2, p. 200, 2018.

[30] W. C. Indhiarta, "Penggunaan N-Gram Pada Analisa Sentimen," pp. 1-18, 2017.

[31] D. Irvantoro, I. Saifudin, and R. Umilasari, "Feature Selection Menggunakan Chi Squared dan N-Gram Dengan Algoritma Naive Bayes Classifier Untuk Analisis Sentimen Review Produk Elektronik,” vol. 53, no. 9, pp. 1689-1699, 2019. 